\title{
Capitalizing on Complicity: \\ Cargo Cults and the Spirit of Modernity \\ on Bali Island (West New Britain)
}

Andrew Lattas, University of Newcastle

\begin{abstract}
Using the cargo cult movement of Dakoa on Bali Island (West New Britain), this article explores the relationship between history and the other forms of human time articulated in cult practices, beliefs, and myths of origins. This relationship often entails the collapsing of historical time into biographical time. It involves Dakoa's cult taking up Western notions of kingship and the Christian figures of God, Jesus, and Moses - all of whom are merged with the heroic structure of traditional myths. New mythological figures have emerged who encompass multiple identities and who resurface at key historical moments so as to give a mythicmagical quality to the transformative processes of government, mission, and commerce. Many of the cult's new important spirit beings are extensions of the cult leader Dakoa, whose personhood embodies a history and provides a model for a new, pacified Melanesian self capable of reincorporating the globalizing processes of modernity.
\end{abstract}

Dakoa's cargo cult movement started around I964, ostensibly as a commercial venture selling copra and trade-store goods (Blythe I995). The movement developed quickly into an independent church with its own cosmology of power and history (see Kapferer I997; Sahlins I98I). Indeed, the movement created a new reality for its followers through its unique mythological reinterpretations of history, which often involved personifying many of the events, activities, institutions, and cultural forms brought by Europeans (Lattas 200I). ${ }^{1}$ Cult followers frequently gave a biographical form to many of the modern institutions and processes that were establishing the new conditions for having social order. In their reinterpretations of history, followers searched for its underlying spirit, or more accurately spirits, as their way of familiarizing and displacing the rationale and

Ethnohistory 52:I (winter 2005)

Copyright (C) 2005 by the American Society for Ethnohistory. 
intelligibility of the new institutions, personnel, and events that were transforming their lives. The comprehensive transformative aspects of Western culture and the comprehensive transformative aspects of mythic thought were merged and relived through each other. There was a desire not just to understand but also to redirect and relive the transformative embrace and utopian potential of modernity (see Knauft 2002; Lattas 2000; LiPuma 2000).

Like other parts of New Britain, from the late I960s and into the I970s Bali was torn apart by conflicts between cult followers and supporters of local council government (Kaunsil) (Counts 1968, I97I). Each group competed with the other in terms of possessing the true road to the white man's world. What angered Kaunsil supporters was the disregard and scorn that cult followers showed toward local government positions and their Western forms of knowledge and development projects. The island's small size and distance from the mainland of New Britain exacerbated the conflicts. Bali (known locally also as Unea and Unyapa) was and still is an overpopulated volcanic island. Approximately six miles in diameter, in 1970 it was recorded as having a population of $4, \mathrm{I} 20$. The island has few flowing rivers, and most of the spring water is in heavy demand. Today, no primary forest or wild pigs are left on the island's three small mountains, and there are few wild birds. Along the coast, fishing is important, and occasionally fish are exchanged for garden crops with interior villagers. Sometimes fish are sold in the provincial capital of Kimbe, though this is hampered by a sixteenhour boat journey. Nowadays villagers rely heavily on rice, tinned meats, biscuits, oil, and other Western foods, which they acquire through working cash crops-mostly copra and cocoa. Much of the island has been planted out with coconut groves, underneath which an additional crop of cocoa is sometimes grown. Subsistence gardens are relatively small and made up mainly of yams, bananas, sweet potato, tapioca, and corn. Villagers tend to avoid large gardens by relying on fruit and nut trees, the abundant yields and fulsome taste of which Bali Islanders proudly proclaim.

In terms of colonial contact, at the beginning of the twentieth century the Germans established a large coconut plantation that occupies about a third of Bali and much of its most fertile land. Many villagers were conscripted to work on Bali Plantation while others were forcibly taken away to work on other plantations in the Bismarck Archipelago. Under Australian colonial rule, there were more voluntary forms of labor recruitment. ${ }^{2}$ Prior to World War II, the Australian administration organized the planting of community coconut groves, and by the r 960 s there was a significant amount of native copra produced on Bali, which helped spawn Dakoa's movement. Like other cargo cults, it criticized villagers who sought their wealth and livelihood away from their home territory (Aquart 200I). 
The arrival of European colonial rule or gavman was praised by all on Bali for putting a stop to warfare between patrilineal clans, warfare that involved eating one's enemies. To ensure compliance with administrative demands, village headmen (luluai and tultul) were appointed; this form of indirect rule continued up until the late 1960 s when local council government was established. In 1932, a German priest known locally as Father Bernard arrived and established the region's Catholic Church. Today it has the largest congregation, followed by Dakoa's cult church and then the Seventh-Day Adventist Church, which arrived in 1958. Other more recent, smaller churches include the Baha'i faith, Assembly of God, and Jehovah's Witnesses. Bali has a number of community schools and a high school, and it is the children of noncult parents who complete high school and go on to tertiary education and employment in towns, businesses, and government departments.

Unlike other parts of New Britain, Bali Island was not invaded during World War II by either Japanese or American soldiers. Nevertheless, men were taken away by the Allies to fight the Japanese in other parts of New Guinea. Prior to World War II, significant disillusionment with the Catholic Church and the Australian administration led some Bali villagers to embrace briefly the cargo cult of Batari (Blythe 1995). It originated in the Nakanai area and spread westward through the nearby Kombei area and as far as the Kaliai bush (McCarthy 1964; Lattas 1998; Valentine 1955). The Batari movement was anti-Catholic and accused European priests of hiding the true talk of the Bible and of holding back the lo (i.e., the law of a new existence to be brought by the dead). Such beliefs are still held by many rural villagers throughout New Britain and are supported by popular stories that tell of how Catholic priests secretly visit graves three days after a death so as to receive money (see Aquart 200I; Lattas I998: I04-6). Dakoa's followers claim to have spied on priests, dressed in black robes, praying in the middle of the night at cemeteries. Likewise, a manager of Bali Plantation was caught suspiciously visiting a cemetery at night. Such incidents confirm cult followers' beliefs that whites have sought to make fools of Papua New Guineans with false knowledge, including false forms of education, self-government and independence, and development focused on individuals and cooperatives.

In I964, under Dakoa's leadership, Bali villagers pooled their resources to form what they call a kampani. Its name, Perukuma Company, is an acronym made from the names of nine villages that donated coconut trees from their community groves to create what followers also call their "plantation." Followers donate labor by working unpaid for their "boss"Dakoa - so that their company can sell copra and accumulate a large profit to rival those of European companies. Dakoa criticizes what he calls bisnis, 
which he distinguishes from the corporate, large-scale undertakings of a "company." Bisnis are the small-scale monetary activities that Melanesians are encouraged to undertake, or such individuals working trade stores and cash crops by themselves or with their families. These are criticized as selfish, wanwan (individualized), commercial activities that are meant to fail and that do not create "love." In contrast, Perukuma Company is celebrated for its love, which is visible in its large-scale communal activities and in followers' donations of labor and coconuts.

More than just a company, Perukuma Company has developed its own ways of localizing not just cash crops and capitalism, but also government and church. In cult church meetings, Dakoa will describe the money produced by Perukuma Company both as "love" and as followers "voting" for him to become "king." Followers' labor is expected to generate enough wealth to create a king for Papua New Guinea, and he will be the "Last King" of the "Last Country," the king of One World Government. In the I960s, when local government councils were introduced, Dakoa's followers refused to vote. Dakoa criticized Kaunsil for not creating peace and love and for not recognizing how companies were the true large-scale aggregates (bung) underpinning the white man's comfortable existence. In the I970s and I980s, followers also refused to participate in national and provincial government elections, and though today followers do vote in all elections, they remain critical of a superficial surface-world government that covers up the true government of the underground. Followers have also rejected mainstream lotu (churches) and have formed their own church called Kalt Misin (Cult Mission), which works with the powers belonging to the ground-namely, the dead and the immortal, transformative creatures known as wowumu or masalai.

For followers, their kampani offers an alternative truer gavman and lotu to the institutions brought by whites, which today have been transferred into the hands of a Melanesian elite that is seen to be corrupt, inefficient, and naive about the white man's ways. As in other cargo cult movements, Dakoa's followers created a new cosmology of secrecy and trickery that allowed them to reinterpret and merge together Western and Melanesian cultural forms (Burridge 1960; Lawrence 1964; Worsley 1970 [1957]). They created new interpretative practices that resituated both the world of the past and the new world of modernity. Followers developed mythic schemes that offered alternative understandings of geography and innovative temporal structures for reimagining the relationship between the past, present, and future. In particular, followers took an interest in Christianity's narratives of pain, suffering, and redemption. These were merged with traditional narratives of punishment and loss, which were also historically recontextualized into the present so as to explain and 
redeem the pain and injustice of race relations. Dakoa's cult elaborated out new mythic schemes, which remade the meaning of villagers' involvement with cash crops, church, and government. Using their mythological understandings of modernity and whites, cult followers took up but also displaced Western institutions, the transformative goals, practices, and organizational forms of which were remediated through the underground. Key white personnel and institutions associated with money, church, and bureaucracy were localized and reexperienced as extensions of the transformative power of local myths, masalai, and dead relatives. The new encompassing global structures that were transforming Melanesian cultures were relived within the framework of local transformative schemes. It was this rendering of local transformations and Western transformations as versions of each other that became the new experience of cosmogony, for it articulated a certain modernization of myth within the myth of modernity.

On the one hand, local institutions, practices, and meanings were redistanced as these became recontextualized and relived within the incorporative embrace of a world economy, global churches, and a far-reaching colonial bureaucracy. On the other hand, these foreign incorporative institutions and processes were familiarized in that they were displaced and understood to have originated and to operate through nearby sites, ancestral heroes, local masalai, dead relatives, and cult practices. Like other cults in New Britain, Dakoa's cult adopted and remade the use of money, church liturgical forms, government administrative procedures, and cash crops. Cult followers carefully studied, copied, and reinterpreted the farreaching aims of colonialism, Christianity, and capitalism, because followers claimed to recognize in those institutions some familiar, hidden transformative spirits. They detected a concealed or secret intelligence whose sweeping transformative spirit seemed to reawaken the sweeping transformative spirits of local sites, myths, ancestral heroes, masalai, and dead relatives. Cult followers began to spiritualize colonialism, Christianity, and capitalism in that they projected their customary transformative spirits - their dead relatives, ancestral heroes, and masalai-into the new all-inclusive structures of Western culture. This was a process of personification and familiarization that involved establishing kinship, exchange and other customary ties that could draw close, but also render reintelligible and renegotiable, the conditions of modernity now controlling people's existence.

\section{Dakoa's Cult}

Among anthropologists, the colonial history of the term cargo cult and its ongoing disparaging popular use in contemporary Papua New Guinea has 
produced much soul searching about the ethics of whether Melanesian millenarian movements should still be called cargo cults (Hermann I992; Kaplan I995; Lattas I999; Lindstrom I993). Yet, ironically, Dakoa's movement calls itself Kalt Misin. Instead of rejecting the "cargo cult" label, it identifies with it and seeks to revalue it by merging it with the pastoral activities of Western churches, the economic activities of large Western companies, and the ordering, civilizing work of government. If asked by outsiders to which church or lotu they belong, Dakoa's followers reply, "Mipela stap long kago kalt" ("We belong to the cargo cult"). Indeed, the words Kalt Misin are painted on cult buildings where followers meet for weekly church services. These are held on Friday because Jesus was killed on Friday and his pain is a piksa (picture, i.e., metaphor, allegory) of followers' hard work and of the punishments they suffered at the hands of council supporters.

The hard work of cult followers involves collecting, cutting, drying, and bagging copra for their kampani. Followers emphasize that they should work unpaid so as to earn the right to share in the future large "profit" that will come from the ground. If Dakoa paid them, then followers would be Dakoa's "fortnightly laborers" who, in having received their monetary compensation, would have no future claims when Dakoa's work finally succeeds in unearthing what is called the New Heaven. Explaining how they have yet to see their true "pay" or "profit" come forth, Dakoa's followers speak of their company having received so far only the local price for copra but not its "world price." The world price is understood to be the higher prices paid by dead relatives who have gone to reside in overseas kantri (countries) like America and who are referred to as one's kandere. ${ }^{3}$ Dakoa explained it like this:

With this price, the price that we receive is not the full price that comes up from whatever we work, like the copra we sell. The copra goes and we receive one price, but it then goes further on and it receives a second price and then a third price and a fourth price. We don't receive these. ... We just receive a small part of it and the big part goes and remains with youse [whites, i.e., underground whites, dead relatives, Americans].

They [underground whites] are gathering it together because they know we are working every day, we are working and the price has to be enough for this [effort]. If we rest then those days do not have pay. . . . the pay remains with all the dead. With all the dead, if we work strongly then they will work the price [an appropriate price]. They have said: "With the [full or world] price, we haven't given it yet because youse do not know us yet. Supposing youse know about 
us, then we will give it and it will come." We know it is like that and we work strongly. It doesn't matter that we receive no money and we receive no food, we still work strongly. If we continue to work like that then they [underground relatives] will feel sorry for us and then they will say, "Oh, give it to them." Now we are not receiving any [significant] pay, we just get what we get but we still work strongly. The big amount [of pay] is there but they haven't given it to us.

Here Dakoa explains how followers need to familiarize themselves with sympathetic underground white men who are collecting the "true price" for followers' hard work with cash crops. It is the underground that motivates and redeems participation in commodity production by making it take on the qualities of an unpaid debt and of emotional blackmail, that is, the qualities of gift exchange. The cult's understanding of "world price" is part of its general refetishization of the language of government, church, and the global economy. In particular, it is the ideological form (and indeed mythological form) given to the experience of labor exploitation, to the experience of commodity production as not compensatory enough in terms of its immediate monetary returns. Yet the cash economy is not completely rejected; instead its structure and price cleavages are used to posit and foretell other, more rewarding worlds of money where money is exchanged as a gift between the living and the dead, and between the races. The underground's covert "world price" for cult followers' labor displaces money and the cash economy into notions of moral debt, into a form of delayed exchange. Here followers work commodities for low prices and in poverty partly so as to make the dead feel sorry for the living relatives who are secretly honoring them.

At cult villages, Dakoa has appointed secretaries who keep detailed records of how many people turn up for work on certain days and what they do. Those records encode the cult's enlarged understandings of work, which includes not just copra work but also followers visiting masalai sites, talking to the dead at cemeteries, cleaning cult houses, and attending cult meetings-all of which has a "price" (underground compensation). The beatings, imprisonment, and humiliation of cult followers by council supporters also has "pay." From followers' accumulating underground wealth, there will emerge a Melanesian king, whom many expect to be Dakoa. His accumulating underground wealth will be his "gold."

Given that Perukuma Company's labor is unpaid and freely given, the work of followers is described as a form of love, which will create a new black Melanesian god who is expected to be Dakoa. The New Heaven will be this forthcoming union of god and king, of love and gold. In weekly church services, Dakoa will preach that "money is love," and this is because 
money marks followers' willingness to come together in peaceful largescale expressions of goodwill that celebrate their sacrifices of time, labor and coconuts. It is money as objectified love that will produce a Melanesian king-god. Though we might regard as distinct the pastoral activities of churches versus the monetary activities of companies, Dakoa's movement has remade the cash economy into a moral domain. A new kind of government will come by making the white man's money recirculate within a moral economy where it generates the love of a new god alongside the gold of a new king. In his sermons, Dakoa will often emphasise how it is important that love cover up (karamap) the work of the kampani (its cash crop activities). The Pisin words bung and kivung are used to describe the cult's new forms of corporateness, its new forms of fellowship and large-scale cooperation. The cult's dual organization as kampani and lotu is recognized to be Western, but it is also seen to continue in a new way the better loving side of custom, such as the communal, moral organizational role of men's houses. There, traditional customs are said to have expressed love through large gatherings that exchanged gifts of food and shell money between different villages and clans. Large customary ceremonies also drew the dead to the living, and Dakoa claims that his large meetings and his followers' production of large amounts of copra for overseas will likewise draw the gaze and presence of the dead to the living. ${ }^{4}$

Dakoa sees himself as preserving and as ruling through a morally edited and improved version of traditional culture. Here I understand Dakoa to be emulating and reworking the colonial project of indirect rule, which used local leaders and a reobjectified, ethically improved form of custom to establish gavman, education, and cash crops (Oppermann 2003). Dakoa describes himself as having selected the good customs both of tumbuna (ancestors) and of white men, while dropping those that are divisive, morally problematic, and incapable of delivering a new existence. It is a cleansed, modernized form of custom that the cult continues along with a customized form of modernity. Kalt Misin and Perukuma Company are celebrated as preferable to the warfare, cannibalism, and sorcery of tradition. They are celebrated as superior institutions for producing love to those offered by official Western institutions such as churches, council government, and copra societies. For followers, their new large-scale Melanesian forms of cooperation and caring will produce a new king and god, who will be a kanaka and who will replace the king and god of white men.

At the beginning and end of cult meetings, Dakoa's followers express their love by shaking hands with each other in long circular lines, which ensures that everyone shakes hands with everyone else. Followers shake 
hands with the left hand, the female gendered side, and this is because as they put it, "Mipela sitdaun olsem meri nau" ("We live-exist like women now"). The male gendered right hand is said to be a "rough person" who strikes others while the female left hand never strikes - the most it does is to be put up so as to block the blows of others. While explaining this, Dakoa related his cult's work to the customary peacemaking work of his clan-Goloki-which used to mediate and resolve disputes between other warring clans on Bali. ${ }^{5}$

When I worked the [cult] work I did so very quietly [gently, peacefully]. I was working the work of all women, but I was a man standing up. But the law of the work that I was working, it was like women were bossing it. I put the name of all women on top of it [cult work] for this reason, because this work is quiet and it is about love, it is about belief. Now, I worked it like that because I stop [exist] with Goloki and I work at straightening all something, and I am like a true woman. I work like them. I am a man, but my work is like a woman because I don't fire up or become cross. I don't talk badly to another man, I don't steal things, I don't swear, I have taken up the thinking of all women. For this reason, woman has name to this work; with this company of mine, woman has a name to it.

Having expelled men's rough customs (pasin) from his work, Dakoa seeks to steer "a course to go to all women and all the good ways." The desire to navigate toward a quiet female self and a more peaceful existence was how followers explained their refusal to respond in kind to the violent attacks of council supporters. Turning the other cheek, followers describe themselves as Christlike in their acceptance of the unorthodox punishments inflicted on them in the post-Independence period (late I970s and early I980s). The punishments included beatings, verbal abuse, being spat upon, made to pull out nails from posts with their teeth and forced to eat coral; men were also compelled to carry women on their shoulders.

Followers often equate the taking up of the left with the nautical imagery of using a "compass" made from the cult's four principles or Foa Kona (Four Corners), which are love, honor, belief, and obeying talk (Lattas 200I). A cult leader at Kumburi village, Tsigomori, explained: "Now, you've come and you've seen us shaking hands with the left hand, and its meaning is like this: we put love, honor, belief, and obeying talk onto the left hand. We follow the left hand, and it is like a woman, we are like women. We no longer fight, like with the right hand. We follow the left hand and it is like this: we have tabooed fighting." As a compass, Foa Kona is also taken to refer to the four corners of the earth, and it is contrasted 
with the symbolic space of white existence, which is described as organized around three corners, as in the three persona of God. It is a more encompassing space for situating existence that followers seek in the world and in themselves. The colonial Christian principles of peace and pacification are resituated (respatialized) and reinternalized back into the gentle goodwill of a process of feminization expressed in the tame etiquette of the left hand. It symbolizes and embodies a quiet self not given to anger or violent outbursts, but Christlike in accepting its humiliation and punishment. But more than this, the colonial civilizing processes, which ended warfare and cannibalism on Bali, are embraced and reowned as a feminization of the self through commodity production. Indeed, Dakoa speaks of his company as a woman and the work of cash crops as a process of becoming woman. Developing this gender symbolism further are procreative references, as when Dakoa speaks of the nine villages of Perukuma Company as representing the nine months a woman takes to give birth.

At Malangae village, cult followers claim to have seen a large egg in the ground, and I was told that the unpaid "pay" and pain of followers has gone into the ground to form this egg. At night, three women under the control of a cult prophet visit this egg in the hope that it will break and deliver the new existence-the New Heaven. Its arrival will coincide with the return of an original lost god called Luangeh (or Mataluangeh) (cf. McPherson 1994; McSwain 1994; Pech 1991; Pomponio 1994; Thurston 1994; Young 1983). He will return with the knowledge and power that he took away and gave to whites. Some Malangae villagers claim to have seen Luangeh's crucified body lying in the ground. This confirms myths that tell how after Luangeh went to America and gave his law to whites, he wanted to return to help his kinsmen, but the Australians became angry that they would have no laborers for their plantations and so they killed Luangeh. However, Luangeh came back to life, and many cult followers believe he has returned to his homeland. One cult prophet, Dau, explained how Luangeh was the "boss of all the wowumu" and his crucified body formed a Foa Kona on Bali: at his four hands and feet where he was nailed there are wowumu, while at his chest where he was speared there lies a bank vault. There Luangeh's blood accumulates and becomes recontextualized, for it becomes equated with followers' unpaid pain and labor, which it will redeem.

Here myth and history are intertwined, with the myth of Luangeh's departure and death explaining the historical need to labor in the present. Another cult prophet, called Devoku, explained how whites had so far benefited exclusively from Luangeh's power and had lived off the top human half of Luangeh's body. However, his lower serpent half, which 
contained his "full power," had been kept "for all of us natives, for all of us black skins." Devoku also depicted Luangeh's return as a snake whose mouth turned back to swallow its tail. Here the head of a story must come back to its origins so as to bring the completed white man's existence back to its lost beginnings with Melanesians. Devoku emphasized that the ability of Melanesians to access Luangeh's power depended on them observing the cult's Foa Kona ethical principles of love, honor, belief, and obeying talk. These Four Corners were described as the laws belonging to new Melanesian "associations," which is the respectable title that some cults in New Britain have taken up (Aquart 200I). Love, honor, belief, and obeying talk are ethical principles given by the "ground" (i.e., by masalai and the dead) for forming a new social order. This will only come about when Melanesians have fully transformed themselves, when there have emerged new Melanesian subjects and subjectivities who embrace and internalize the pastoral project of peaceful submission. Devoku portrayed Dakoa as the exemplary model of the new pacified Melanesian subject: as a quiet, suffering subject whose pain and labor will be redeemed by the spirits of the dead and the wowumu housed in the ground (in stones and mountains).

If the two of us tried hard to follow ideas about love, honor, belief, and obeying talk, then the two of us would be following the laws of lotu [church, i.e., Kalt Misin]. We would be following the [Perukuma] Company and working it [the company] to have honor. The two of us would go and turn this [honor] so that it went to a new king belonging to us. He [the new king] is here now, he is here and thus there is now no fighting, there is no strife. He follows [bihainim] the blood that has been spilt up until now. The world [underground dead] and the stones and the mountains [masalai] will all come together, and be put together with the pain and they will talk, "You are the new king." Now I believe in the new [cult] knowledge that has been given to me; we are now close to becoming like youse [whites]. I know that he [Dakoa] will become our king.

The first time, they [whites] were schooled in his [Luangeh's] knowledge, and this made something come up. They all put together one thinking to go to him and they made come up a king belonging to them alone. It is not as though I [as an individual] can work and acquire knowledge and then just go and go all the way. I must have a boss and I must have a king. I know that a new king is close to coming up who will belong to us alone. He will have his own money, he will have his own bank, he will have his own wholesale [store for supplying cargo]. 
Devoku's above statement expresses a desire for political, economic, and pastoral independence. He wants a church, a god, a company, laws, and forms of sovereignty that do not come from Europeans but are homegrown. There is also a desire to own and to reground the governmental conditions for being an ordered subject, and this is exemplified in a kanaka king who brings peace, law, and wealth. Dakoa is described as following the blood that has been spilt; he atones for and redeems this blood, which is a metaphor for the pain and labor of his followers. In the form of a cult church and company, followers' labor and pain are transformed into the hidden wealth of a new king, into a subtext of capitalist expansion, and into an authorizing form of sovereignty that relocates and regrounds the processes for producing value.

The cult is proud of its production of ordered pastoral subjects through its Foa Kona of honor, love, belief, and obeying talk. Even noncult opponents praise the peacefulness and orderliness of Dakoa's followers. It is not just a question of Dakoa alone becoming king but of everybody having a chance to become a king through sharing in Dakoa's wealth. What's more, Dakoa's exemplary moral personhood and his Foa Kona ethical principles will make everybody into God. As Devoku put it:

Everything that is ready will come to us through pain and honor, we will make it come up so that we "shake" [sek, become startled, possessed], it will come up as a church. The church will go and go and we will gain knowledge and then this person here will be God and that person over there will be God. If you are a good Christian then you will come up and become like God-you will be God and I will be God and so will he [a third person] also be God, all of us will be.

It is a certain democratization of king and god that followers ultimately seek when celebrating Dakoa as their exemplary leader, as the new model for pacified Melanesian personhood. Followers speak of acquiring Dakoa's spirit, known as CDT, an abbreviation for Dakoa's full European name of Cherry Dakoa Takaili. CDT is an underground white spirit, a masta, and through the work of Perukuma Company and Kalt Misin, CDT will become a spirit who will inhabit each follower so as to transform them into God. It is then that people will shed their black skins so as to sit down like whites. What is Perukuma Company if not the embracement and active embodiment of hegemonic processes of westernization, which are experienced and lived out as processes for being whitened? In Perukuma Company, the transformative promises of government, church, and cash crops are displaced and remade through a familiar terrain of local spiritsthrough the customary transformative promise of the ground. Here there 
is a merging of promises and transformative powers. The hegemonic processes of modernity are displaced and remediated through the customary concealing properties of the earth, through familiar forms of secrecy, through recognized strategies of concealment and disclosure. On the one hand, the complicity of cult followers with processes of pacification, Christianization, and development are remediated through a certain hermeneutics of disclosure that forms a world through those doubled worlds of meanings offered by what the earth hides and reveals. On the other hand, these customary earthly ways of grounding secrecy, truth, and disclosure are relit, shown in a new light, by the new unseen or veiled realms of modernity-God, world prices, big government, and the empowering/sacred geographies of Europeans like America, Australia, the ancient Middle East, and Heaven.

\section{Names, Multiple Identities, and History}

Dakoa believes that the original personnel and institutions of commerce, government, and mission that came to Bali were foretelling and preparing for his work. He interprets prominent early white men as spiritual versions of himself, as underground Dakoas, who came to start the work of bringing peace and love. Dakoa has three underground spirits who together with his "shirt" [body-embodied surface self] form a Foa Kona. Dakoa's three underground spirits are his own spirit called CDT, a wowumu stone called Dakoa, and the spirit of a dead man who was named Dakoa while alive and who assumed the name LTD when he died. Each of these spirits is referred to as a "Capital D"; they are capitalized versions of Dakoa and secret signatures in the world. Dakoa is aware of the various meanings of the English word capital and he enjoys merging the economic importance of capital with the symbolic importance of capital letters. ${ }^{6}$ LTD is the spirit of a big man called Dakoa who died and then went to "boss" all of the world's large companies. This is why his name is found at the end of the names of large companies. It is because he is one of Dakoa's spirits that large European companies prosper and do not go bankrupt. The name LTD also has power because it is an acronym, a symbolic abbreviation and condensation of other names and identities: $L$ stands for Luangeh, $T$ for Takaili or Dakoa's deceased father, and $D$ for the cult leader Dakoa.

Dakoa uses his spiritual namesakes to expand and globalize his identity and to draw the transformative processes of myth and modernity into a mirror image of himself. There is a certain self-love or narcissism in Dakoa's version of history. He derives genuine pleasure from contemplating and admiring his participation in the transformative projects of history. 
Yet more than a personal fixation, this merging of history with biography is also the essence of myth, which uses the actions of heroes to give generative form to the world (Eliade 1954, I959, I963; Hegel 1975). Dakoa's incorporation of the flow of historical time into his life serves to mythologize the present world so that it repeats an archetypal originary presence. It is this desire to recapture the transformative power of myth that followers seek when they expand Dakoa's personhood in time and space so as to encompass the ancestral past and so as to rework it into the transformative, historical moments of global incorporation. Thus, for example, Dakoa claims that his wowumu namesake started Bali Plantation. According to Dakoa, Bali Plantation was not appropriated by the Germans but given to them by Bali's underground white men: "This Dakoa made the plantation come up. This huge one that is here, it belongs to him. He marked it, and all the Germans came. It didn't belong to all the Germans. It was this wowumu who marked it."

More recently, this wowumu came to the surface and told Dakoa, "With this plantation, it is not as though all the white men acquired it for nothing [without reason and for no compensation]. It was me alone, the papa bilong graun [father/owner of the ground] who gave it to them." Dakoa expects Bali Plantation to be later transferred into the hands of his cult. Given that the creator of this plantation was his spiritual namesake, an empowered version of himself, Dakoa regards himself as the secret, true manager of Bali Plantation. This is cryptically confirmed in official letters sent to Dakoa that arrive addressed: "Dakoa Takaili, c/o Manager, Bali Plantation."

Dakoa holds regular conversations with the underground, and he speaks with this Dakoa wowumu who surveyed, cleared and planted Bali Plantation. It was this underground white Dakoa who advised his surface double to start his own cult company around copra: "He gave thinking to me, and I stood up the company." Later this same wowumu and the spirit LTD came to the surface world as two white kiaps (government patrol officers) who took Dakoa into government offices so he could "register" his company. Dakoa interprets interactions with sympathetic, surface white men as disguised interactions with underground beings. Given the naive yet self-assured knowledge of contemporary Melanesians, the underground is understood as needing to hide or mask itself, and so its underground beings turn into white men when they need to surface. Sometimes the necessity to hide means that wowumu prefer not to surface but instead influence the thinking of surface whites. Dakoa believes they did this so that the Germans came and cleared the land for Bali Plantation. "It was because of all these wowumu. They didn't come up into the open for this is taboo. They 
gave it [thinking] slowly, it came from those inside, and then the Germans came, and they took all the men to come and clear it."

In terms of Dakoa's own company and cult work, Dakoa's wowumu informed him, "We will just help you, but we can't come up into the open. We must hide. We will make it strong, but you will control it." Later this Dakoa wowumu did come out into the open and it was together with LTD; they both came as the white kiaps who advised Dakoa how to go about registering his company. Dakoa speaks proudly of how they took him into different government offices where white personnel had to listen attentively and record his wishes.

He [Dakoa-wowumu] came and we worked together, he came out into the open. He was a masta. He came out into the open, and together with me we went to the office. We went inside the office, and he told me how to talk. He said, "You must say this and that, and they will work it. They have to listen to you." When I spoke, they wrote it down, and when we went into another office, it was the same.

It is a certain power over whites and government, a certain reversal of the bureaucratic power of race, that is celebrated in Dakoa's frequent retelling of this story. The world of colonial bureaucracy is inverted with it now obeying the wishes of a kanaka. Given that Dakoa regards these government officers as underground white men, he also speaks of himself as having registered his company with the ground.

White men who distinguish themselves in the surface world through kindness and moral support are often familiarized by cult followers into dead relatives or localized into ancestral wowumu. In becoming indigenized they are elevated into more powerful kinds of white men, "mixed race" kiaps who secretly recognize the force of names, kinship bonds, and custom. In the form of these ambiguous kiaps, who helped register Perukuma Company, another kind of government is envisaged. Here Western powers of government are appropriated and familiarized, with bureaucracy becoming secretly inhabited by the alternative government of custom. Different laws (lo) are secretly made to overlap and to inhabit each other. The power of Melanesians to manipulate modernity, its offices and company structures, can only be successfully realized through the secret power of the ground, through the hidden presence of customary powers that are governed by locality, names, and kinship. Yet the Melanesian character of this power and alternative lo must be concealed in whiteness. What is resistance and empowerment here if not reownership and control of concealment and camouflage? It is a certain government of disguise, a custom of masks, which has to be preserved and reinvented (Taussig 1999). The struggle for 
cultural autonomy is always a struggle for secrets, and cargo cults merge the new mysteries of bureaucracy, church, and corporations with the traditional secrets of the ground and of men's masks. Yet this struggle to reinvent and reown control of secrecy, concealment, and camouflage is a struggle to maintain control of the hermeneutic conditions of one's existence; that is, the hidden layers of meaning that call forth interpretation, that call forth a world through the hiddenness of the earth (Heidegger 1977).

Certain underground white voices speak to Dakoa and his followers, and they travel around with them influencing their thoughts, desires, and actions. When cult followers were jailed in the r970s, the underground American spirits or "opposites" (opsait) who at the time possessed many of them also went to jail with them. A certain racial dialogical structure inhabits and organizes cult followers' thinking and identity. I believe it is the hegemonic internalization of white colonial voices, reobjectified and reowned as familiar underground spirits, that now surfaces to guide Dakoa and his followers through the new maze of Western institutions, offices, documents, and cash crops. Who or what are these subterranean whites except perhaps the internalized echoed voices and forms of knowledge of Europeans, which are merged and retrieved through the reverberating local powers of the ground? The hegemonic subjective aspects of modernity are relived anew as villagers find new ways of situating the hegemonic presence of racial authority and new ways of living with their underground white consciences. Cultural resistance here requires keeping the externality of the Other so as to remake whiteness through a dialogue that appropriates its authority. The guiding moral and intellectual presence of European culture is not totally subjectified; rather, its full hegemonic internalization is denied by being partly relived as external autochthonous voices and spirits who guide one's thinking and can repossess one's identity.

It was reputedly the hard work of cult followers with cash crops that led the two kiaps to come and register Perukuma Company. In Rabaul, they took Dakoa to visit another white officer who asked Dakoa from where he would later acquire his cargo and Dakoa replied, "From BP." Publicly, this was taken to mean the wholesaler Burns Philip \& Company, but Dakoa's reply was also built on a secret understanding of $B P$ as an acronym for Bali People. Indeed, Burns Philip was believed to ship secretly its cargo from one of Bali Island's three mountains-Bibimi. The white officer confirmed Dakoa's secret understanding by informing him: "I want you to do that, I want you to get cargo from BP. It is from BP that all the masters acquire cargo, that they receive ships, that they receive planes. $\mathrm{BP}$ is the boss of everything. Later, you must also receive cargo from BP.” After this inspiring meeting, Dakoa visited and informed "the number one person belonging 
to $\mathrm{BP}$ ” that he wanted a tractor. With his order he gave $\$ 3,300$ for a tractor and trailer, which his followers later used to collect copra from around Bali Island. On the advice of the manager of Bali Plantation, Dakoa also bought shares in Bougainville Copper Limited (BCL) and prior to the rebellion on Bougainville received yearly dividends. Dakoa understands BCL to have been run by the underground spirit LTD, but its success angered the rival Bougainville leader Francis Ona who then, out of jealousy, sought to destroy BCL.

\section{Lotu, Gavman, and Kampani}

Within Dakoa's cult there is an ongoing reappropriation of modernity's new conditions of existence, with followers reinternalizing and resituating the history of projects of development and pacification. According to Dakoa, the Catholic Church on Bali was established not simply by a German priest, Father Bernard, but by the spirit known as LTD, who changed (goligoli) and came into the surface world as Father Bernard. At the time, Dakoa was a young boy, and Father Bernard was so impressed with his abilities that he appointed Dakoa to lead a small church group. On Sunday, Dakoa would stand next to a blackboard and instruct other young boys in singing and in "counting all the numbers" (identifying European symbols). Today Dakoa still enjoys preaching from a blackboard, which he equates with the way Moses and Jesus previously taught the Law. On a blackboard, Dakoa will draw pictures and write down names and abbreviations that elucidate the overseas powers hidden in the ground. He will explain how the Catholic Church is really a company, like Perukuma Company, because it assembles together large numbers of people for the purpose of collecting money, and this is said to be what all companies do. For Dakoa, it makes perfect sense that the Catholic Church on Bali was started by LTD, by the same spirit that "went and got up all the companies." Given that this spirit secretly runs all the large European companies that supply cargo, LTD is also known as D-Supply, which Dakoa explained as follows: "He goligoli [changed], and he came as a priest. He put the first church on Bali. There wasn't another priest who put the church on Bali; it was this man here, this D, D-Supply. This D here, this wannem [namesake] of mine, he died and left, and he then became a priest and came back and worked a lotu [church]."

Dakoa claims Father Bernard wanted to take him away to train him as a priest but Dakoa's father opposed the suggestion because he had only one living son. Dakoa then explained how he stayed and started his own company and "it was he [Father Bernard as LTD] who came [as a white 
kiap] and registered it in a book. It was this man alone. Now, this man, he was not a true priest. He was a daiman [dead man]."

According to Dakoa, true change will not come from the mainland of Papua New Guinea but from Bali. The mainland is accused of having too many bush people who are kaulong (backward, ignorant), which makes it too hard for surface white men and government to undertake the work of economic and moral progress. However, because of its small size, Bali is seen to be the ideal environment to produce social change, and this will be through Dakoa's work. It will later spread the government's economic and moral enlightenment projects throughout the nation. Dakoa studies and internalizes the meanings of government actions, and he holds conversations with the spirit of government, with the hidden intentionality that he discerns in government practices and which he then reobjectifies and personifies as underground spirits, what he calls kontrol bilong mipela (our control). It is certain governmental voices and powers that Dakoa reproduces in the white voices that talk to him about Bali being the prime mover of social change and moral enlightenment in Papua New Guinea. Dakoa speaks in the name of gavman and this is an underground government, a true government of the future belonging to Bali and that will later belong to all in Papua New Guineans.

The gavman said, "The people of Bali will change first, and all of those of the big ground [mainland] will change later, much later. It is like this: we [gavman] will school some along the coast, but some of those who are truly on top [in the bush], who will school them? We went on top and we spoke to them all, but they didn't listen. Well, they will have to wait [for the change], it will come later. Bali will change first, and it will then school all of those belonging to the big ground. It is not as though they [the mainland] will come to school youse. No, for they have plenty of kaulong [backward villagers] and it's going to be hard with them. But Bali doesn't have plenty of kaulong. There's only just them there, and, if they say 'yes' to following your [Dakoa's] talk, then it will be finished. We white men will come to support you to get up some good roads and to work a water supply. Youse can then sit down. We will do this. We will live with youse."

Here Bali's small-island status and the fact that it was colonized early makes it the perfect self-contained vehicle for the work of social change brought by whites and that secretly comes from the ground. When Dakoa talks with gavman, with its spirits, the discussion is about the need for his cult to take up and disseminate the government's pedagogic task of creating moral, disciplined subjects who will be peaceful while working 
hard with cash crops. The government's moral and economic tasks are displaced away from surface white men and especially away from Melanesians in governmental institutions so as to be truly realized by Dakoa's cult work.

The underground whites became tired of Papua New Guineans acting like fools, and they came to Bali in the form of Germans to begin the schooling process by starting Bali Plantation and the Catholic Church. These white spirits have returned at different times to help Dakoa start his work. In 1973, they came as American spirits who possessed Dakoa's followers. Cult followers became possessed by white deceased relatives so that old men and women who did not know how to speak Pisin did so. Some villagers even claimed the ability to speak English and Latin. Their "boss," President John Kennedy, led these American spirits who taught followers how to work with the ground. Later, these white spirits returned, but in the form of Australian army personnel who built a water supply and today in the form of an Australian anthropologist who comes regularly to check on the cult's work. Dakoa believes that I am his deceased brother, Albert, while the head of the Australian army work brigade was another deceased brother, Mateyo. With respect to myself, Dakoa told me: "I recognize you. You are my brother, and you used to come and possess the shirt [body] of this man over there, Raveh. You used to possess his shirt, and you used to talk with me all the time. It is truly good that I now see you coming straight [i.e., not mediated by another body], for you are my brother." In the I970s when Albert came as an American spirit inside Raveh's body, he urged followers to work hard and not be lazy. He warned against the false talk "from council and from businessmen and from all these men who know about paper" and how these educated men would "come to work some talk that doesn't have meaning."

He [Albert] told me [Dakoa] that I couldn't listen to their talk, and that I had to follow his talk that went straight to all kandere. He helped us with good love and belief. "We kandere have come for this reason. You have won us with good love and belief. It is for that reason we have come to help you, and you must work strong. You can't be lazy. You must work strongly, and we will all then come back. I have come in advance so as to give you this talk, so that you can receive my thinking."

Today cult followers are waiting for the American spirits to return only this time as embodied white men. Many expected them to come in the year 2000. In the I970s they came hidden in the shirts of Melanesians, for as Albert explained to Dakoa: "When we come, we have to hide. If there is 
a shirt, I can come. Now, supposing there isn't a shirt, then I can't come out into the open because of all those who work at deceiving youse." It is divisions between Melanesians that prevent the coming of a new world of racial reconciliation where the dead and the living can openly recognize each other.

Currently, many followers believe that if they recognize a surface white man to be a deceased relative then they are duty bound to conceal this so as to protect his clandestine presence and support from the anger of council supporters. Followers see themselves as doing this with myself, and it was also done to Dakoa's brother, Mateyo, when he came in the I970s as the head of an Australian Army work brigade. In that form, Mateyo came to build water tanks and install pumps. Before he left, this army officer visited Dakoa at Penata village and reportedly told Dakoa how he had been sent away by the council. ${ }^{7}$

I came because I truly was worried about you, and now they have expelled [rausim] me, so I can't talk with you. Brother, I have wanted to come and talk with you, but if I were to talk to you and call your name, then you would cry, so maski [let's leave it]. I came from Moresby and there they changed my name. I live in New York along with papa, the father of the two of us, who married two women. They all live over there.

Here Dakoa posits another more familiar kind of whiteness: a white man married to two women, and a brotherhood that crosses the races. Here brothers discover a unity in secrecy, in secrets about death and America. Here there is a relationship of pathos where brothers in the existing world keep their distance so as to protect each other, so as not to startle each other with the intensity of their hidden closeness. Here the dead come to help the living but they cannot disclose that they have been brought by the cult's work and so they disguise themselves as army personnel. What is whiteness here if not the new conditions of trickery, of disguise? Moreover, it is people's forms of complicity with white power that are here being renegotiated and repossessed. No doubt Dakoa's cult was seeking to empower itself through aligning itself with the new practical and beneficial work of white men in the surface world, but the cult was also articulating a certain ontology of power (Kapferer 1988, 1997). It was articulating a particular kind of relationship between knowledge and power that involved a hermeneutics of suspicion; that involved certain ways of aligning identities so as to create more compromising and disguised ways of being black and white, of being Melanesian and European.

After Mateyo left Bali, disputes between noncult villagers led some to 
cut several of the new water pipes. For cult followers, this is indicative of the pedagogic failure of both the Catholic Church and the council to transform villagers in moral terms so that they can recognize what is good for others and themselves. It is within a certain moral problematic of race that Dakoa inscribes his cult work. He takes up the moral and intellectual critique of Melanesians articulated by Europeans and Western institutions, using it to bolster his own alignment with whiteness, with underground forms of control.

Later, after his army brother left Bali, Dakoa received a letter from him which council supporters saw and exclaimed: "Ttt! This is not a letter belonging to the men who have died. It belongs to a kuskus [secretary]." Knowing differently, Dakoa and his followers took the letter and hid it for fear of antagonizing council supporters. Dakoa went on to tell me how Mateyo was young when he died, how he was Dakoa's father's firstborn child who was killed by sorcery, and how:

He then went down to all the masters and there he became big [important]. He married there and he had children with a misis. Later, he came back and he worked these tanks of water. He told me, "I am your brother. I am Mateyo. I came from Moresby and they all changed me [made him white, disguised him]." I said, "It doesn't matter. There is later. You can now work. Later, something will happen, and we will recognise each other."

Later there will be recognition of familiarity between the races, but for now the pathos of race is the distance that close relatives must maintain from each other as a duty of care to each other. These are the subtexts of the colonial encounter where the coerciveness of racial encounters are counterbalanced with subterranean relationships that hint at other ways of being white and at other ways of being Melanesian. It is these new, compromised ways of being white and these new, compromised ways of being Melanesian that are being experimented with, that become reterritorialized and unearthed as a domain of shared secrecy between the races; as something to be known but not now known.

When a white kiap warned cult followers not to fill up a forty-fourgallon drum with money that followers claimed they were finding coming up from the ground, this was taken as a warning by an underground masta to be humble and not boastful of cult successes. ${ }^{8} \mathrm{~A}$ white spirit was warning followers of the need to hide their successes with ground. When the Catholic priest Father Rose became disturbed by the jailing of cult followers for the nonpayment of council taxes, which he then paid, this was seen as an underground white man coming to help cult followers against angry Mela- 
nesians (council supporters) who did not know how to govern peacefully and with love.

Dakoa's rejection of the legitimacy of council government was expressed in his initial refusal to pay council taxes. Yet Dakoa had in previous years paid other kinds of government taxes, namely company taxes on behalf of Perukuma Company. Dakoa paid his company taxes to the Taxation Office in Rabaul where in 1967 he was recorded as carrying a small chest containing $\$ 400$ or $\$ 500$ along with the names of followers who had contributed the required taxes. Taxation officials were puzzled by this list of names, which for cult followers was them paying "taxes" so as to be "registered" with the ground, with ol masta and kandere. Money is often collected and used in Dakoa's cult to draw the lukluk or luksave [gaze] of the dead to the living, so that cult followers can be recognized (registered) by those secretly accumulating the cargo and preparing the new existence. Previous ways of being known by the ground that were customarily organized around clans, masalai sites, gifts, and ceremonies are transferred to the realm of government, race, and money.

Dakoa interpreted his company taxes as a gift of money to special white men in Port Moresby, to kandere and to a clandestine underground government, so they could look after his company and allow it to prosper: "If you work for a company, then the company must have meaning by working at paying taxes. These went to the office and they would then give money [copra returns] to come back to me." Dakoa would take his dockets or copra receipts, what he calls "the meaning of all the copra," to the taxation office and it would add them up. He spoke of how his company would fail if "the Taxation Office did not work good this money," that is, the taxes he gave it, and it might do this because he and his followers had not executed their cult/company work properly (through proper moral and ritual behaviour as well as copra work). For Dakoa, the taxation officers were underground masta checking on the economic and moral health of his company, and they shared in its profits, for which they were partly responsible.

All the white men of Port Moresby would come and they would tax us. . . We would straighten the taxes at the office and we would then receive the work-money [copra money], it would then come. They would give me money, profit from copra. They would give me like $\mathrm{I}, 000$ or 2,000 or 3,000 or 4,000 [dollars] at this time. They would send my pay to come and then we would again pay taxes to the office. We would tax for this money [copra money].

The meaning of taxation is here inverted, for it is read not as a tax on achieved profits but a tax so as to receive profits. ${ }^{9}$ Dakoa's "profit" included 
dividends from his shares in Bougainville Copper Limited. Its abbreviations are understood as secretly signifying Dakoa's work: $B$ for Bali, $C$ for Cherry, and $L$ for the spirit LTD.

Dakoa's followers believe that their copra profits, which they deposited in the Commonwealth Bank in the late I960s and early I970s, provided the money for the formation of the Papua New Guinea Banking Corporation (PNGBC). With independence, it was cult money that is said to have created the new national bank that would store the future wealth of Melanesians. It was cargo cult work and money that led to the departure of the bank belonging to ol masta (Commonwealth Bank) and to the formation of PNGBC as a symbol and vehicle for Papua New Guinea's promised economic independence, which for the cult would ultimately come from the ground. At this time, followers were finding rice, money, kerosene, and flags, all coming up from the ground. Dakoa explained how they also found two checks valued at around $\$ 20,000 . .^{10}$

Those two [checks] came, the meaning came, and we straightened the house [of Papua New Guinea]. We received this [PNGBC] bank. They said, "It's your bank. It doesn't belong to us. It's from your ground." Now we black skins are happy because we have our bank but supposing we didn't have this something [cult work], then we wouldn't have a bank. We would just work with the bank of ol masta and they would work with all the money and we wouldn't have any. However, we worked stronger and stronger, and this [the checks] came into the open. We stood up this corporation [PNGBC], this corporation doesn't have a small amount of money - it has a large amount of money. It was money from kandere and kandere said, "It is not our money. It is your money. We don't have money like that. . . . Youse worked hard cutting copra and cutting copra, and this [cult] work has stood up plenty of things. You must take this [the checks] and put them in the bank so something can come up." All right, we went and took them and we went and put them in [deposited them] and the bank [PNGBC] came up. This bank is not just something belonging to ol masta, it is something belonging to us. It is like this: my name was sent and it resides with this bank. It is what they call D-Supply.

Dakoa speaks of the time prior to 1973 as a time when he just worked a company and when his work had yet to join firmly with the ground. After 1973, Dakoa stopped paying his taxes to surface white men in government offices and instead chose to give his money directly to ol masta in the ground, for the former were suspected of not passing on the money to the underground white men. ${ }^{11} \mathrm{He}$ explained, "All right, we hadn't yet received the [work of the] ground. . . It was in 1973 that we joined to the ground 
and it was then that the work was of two kinds. There was the work of the ground and the work of coconuts. Now, for that reason, these taxes to the office, we stopped them. We didn't work them anymore; instead the money now went down below [Dakoa points with his hands], down there."

When I asked why he stopped paying taxes to the Taxation Office, Dakoa replied that the ground told him that he should no longer look to above-ground white men but to it: "You must look to me. For now, I have taken their place. I will work the work and you will look towards me. If I want money, then you will give it to me." The underground masta were described as working with Dakoa's deceased first wife, and it was she who provided Dakoa with an overseas road to kandere (overseas dead). Dakoa explained: "She takes the money and she supplies it to all the countries." This money buys off white men so they can later come and work for the cult. It also buys off envious white men, who (jealous of the cult's success) might intervene to block the work of Perukuma Company. In the early I970s, Dakoa's cult was at its most prosperous, and Dakoa speaks proudly of how "at this time, all the profits were coming to me and I was working plenty of corrugated iron houses." Dakoa built three such houses at the villages of Penata, Kumburi, and Rukaboroko from the so-called "profits" from copra, which at the time was between $\$ 2,000$ and $\$ 4,000$ annually. He describes himself then as "working to find the road for working some big work" and so he blocked one road, the payment of taxes to surface masta, so his money could work more effectively through the advice provided by those down below. They reportedly told him:

This work that you all work toward Port Moresby [surface whites in the taxation office], we have come to block it. Youse cannot send your money to go over to there. Youse must look toward us. We are your kandere and we are here. They too [above ground whites in the taxation office] are like kandere, but they are another company and we are another company. Youse all know us, we work together, and youse are joined to the ground, now youse all must work with us.

We have a new form of company allegiance, a new alliance with whiteness and the kandere who are producing profits for the living. The underground relatives in the taxation office are disclosed to be really a cover for the true power that will come from the ground: "In the office, they also were kandere, however this here [above-ground kandere] was covering up the others [below-ground kandere]." The relationship between these two groups of white men was far from perfect. Not only were those in the taxation office accused by the underground of not passing on cult money to them, but they were also accused of "hiding their thinking" from the under- 
ground. Dakoa was instructed to work in future directly with the ground, rather than in this roundabout way through surface government structures. It is the forms of one's complicity with whiteness and modernity that are here being renegotiated as Dakoa starts to move his cult's labors away from cash crops and taxes and toward a church that works with the ground. The work of money is redirected so that it circulates meanings in a new way, so that it circulates whiteness in a new way that regrounds it closer to home. Today, at a stone at Penata village, Dakoa will leave money collected from his followers along with reports written by his secretaries about how many people attended meetings, what was said, how many people cut copra, and how many worked during the night at cemeteries and masalai sites. It is a direct form of communication with underground whites that Dakoa implements as a sign that things nowadays are close to happening.

Though he often idealizes white men, especially those in the underground, Dakoa is also critical of the economic exploitation of Papua New Guineans by Europeans. He sees his kampani as a solution to the white man's tricks of pulling money exclusively toward themselves.

It is like this: some of the times youse [whites] trick all the Kanakas. Youse make it so that all of their food and money is pulled toward youse and becomes yours. It's for that reason that we have made this [company] come up. We received a little bit of knowledge from ol masta, and we then recognized things [luksave], and we then wanted to work it ourselves. It was then that these two spirits [CDT and LTD] came back again, and they stopped inside [the cult's work]. They had previously shown Bali Plantation to all the white men; they had worked it. They said, "Youse [Germans] can work it, but later we will take it back. We will take it back when all of the people come strongly [into Dakoa's work] and they [followers] talk about taking it back, for it doesn't belong to youse."

Though critical of whites, Dakoa cannot break away from the moral and intellectual hegemony of whiteness, and so he proceeds by reinternalizing and remaking its guiding light. Dakoa colludes with underground white spirits to create a hidden history of complicity with colonialism and modernity. The same masters who started Bali Plantation are secretly operating in his cult work, are secretly guiding and strengthening it. The ground repersonifies itself; its talk and intelligence resurface anew. The ground here operates very much like Elizabeth Povinelli (1993) describes for Australian Aborigines, as a sentient being that has perception, consciousness, language, and a capacity to act meaningfully. It is not just the dead in the ground at cemeteries, but also rocks and trees that listen and speak 
back so as to steer the living. They now do so not just to guide the living through their own local terrain but through the new terrain of government, church and money, for it is these new institutions that are made to work secretly with the ground. The ground's intelligence comes back to its kinsmen as white people so as to mediate this alternative modernity. Dakoa uses these underground white spirits to authorize acceptance of some of the new encroaching structures of modernity while resisting others such as council government, education, and working cash crops individually. When Dakoa criticizes schools, it is because they do not teach how to converse with the knowledge that lies in the ground, which includes "the ways belonging to Four Corners."

When in the late I960s, Dakoa's movement refused to join council government, many councillors were outraged, and they successfully demanded the imprisonment of cult followers for not paying council taxes and for not turning up on council work days. The Australian kiaps on Bali often took a more conciliatory line, which angered council supporters and which Dakoa explained as due to the fact that this "underground Dakoa, this stone, entered the thinking of these white men and worked the stomach of gavman to go cold so that it was no longer strong and hot towards us, towards gaoling us." This underground Dakoa who blocked the angry thoughts of gavman was the same Dakoa wowumu who became a white man and traveled with Dakoa to colonial administrative centers like Talasea and Rabaul: "We walked around together continuously and he helped me when I went to the offices." It is a new form of spiritual companionship that contemporary Melanesians seek to create, so as to draw close white men in complicated layers of conspiracy and complicity, where the social order of modernity becomes predicated on knowing not to know whom this white kiap really is. One interacts with him as though he were just a white man while all along rereading him as a spiritual double, as a familiar ancestral stone.

Dakoa sees himself as protected by his white masalai double, by this underground-empowered version of himself. He and his followers have been arrested and jailed many times and have received beatings from netif (native) policemen and councillors. Those punishments are repeatedly equated with those that Christ received at the hands of the government of his day. On one occasion, followers feared that Dakoa would die, for his ribs had been broken, his face was severely swollen, and blood was flowing freely from his mouth. The fact that Dakoa survived, along with his present good health and old age, are part of his mystique-some say that he will never die. According to Dakoa, during conflicts with councillors his wowumu came and put a brake on their excesses. At the time, he reportedly asked a white kiap if they intended to kill him like the time white men 
had killed Jesus, but the kiap replied: "We are not going to kill you because there is a man standing up over there." Dakoa claims the kiap was referring to Dakoa wowumu and that white kiaps knew and were afraid of his underground namesake. For this reason, Dakoa was not surprised to find that white kiaps were not as cross toward him as councillors who could not understand the more conciliatory, humanitarian approach of their colonial superiors.

According to Dakoa, his imprisonment by Australian kiaps was them needing to give the illusion of supporting local councillors by condemning his cult's work. Their punishment was meant to be only a token punishment; it was not meant to squash his work but allow it to survive.

My thinking works in a different way. It goes and goes, and it weighed up all of the thinking belonging to whites. I then became pig-headed. With all the talk, they [councillors] said I became pig-headed. Well, the government said, "You are not pig-headed. You just want to work this something belonging to you, and that's all right. I will punish you just a little bit. It will be a small punishment, and you can keep working. I will be punishing you, but I will not be blocking your road. The road is still there."

Dakoa reads subtexts of complicity into colonial administrative practices and policies so as to draw out another kind of government for himself and his followers. He understands himself as having developed a clandestine relationship with white officials where they were not really punishing him but were testing him and seeking to cover up their support for his work. When Dakoa's followers were arrested they noticed how Europeans showed more tolerance of their cult activities. They recount how kiaps would apologize to them and blame pressure from council leaders for their arrest and jailing. For cult followers, these apologies and the relatively milder punishment of imprisonment (as opposed to council beatings) came from the underground. It needed a cover to operate in this world, and so it was pulled along by the rough antics of angry Melanesians who did not really know how to govern through love. To rationalize the milder punishment that white men inflicted and the trials and tribulations suffered at the hands of council supporters, cult followers drew on beliefs that nothing comes freely, that belief and faith need to be tested, and that all suffering will be redeemed. The themes of sacrifice, which ran through both traditional culture and Christianity, were drawn together to create a complicated conspiracy between whites and Melanesians where the underground meanings given to the coercive colonial encounter served morally to redeem white men and the coercive pains and labors of the living.

One thing that cult followers were punished for was digging up the 
bodies of the recently deceased. Indeed in 1976 some followers ate the flesh and drank the "water" or "soup" from these bodies so they could be close and not afraid of the dead, and so they could see what the dead could seewhat was in the ground and what white men hid. Followers spoke of their actions as the cult's form of the Holy Communion, which helped them to take on the dead's lukluk (vision, gaze) and save (knowledge). Earlier, in 1975 , followers had sought to internalize this clandestine white knowledge by having American spirits or opsait (opposites) enter them. All of this was happening around the time of political independence, and it was the cult's way of appropriating and internalizing the government of whiteness, of empowering Melanesian autonomy through distinctive Melanesian ways for internalizing other knowledges, identifications, and powers. It was a unique reshaping of official projects where Melanesians would now take over from whites, where Melanesians would now assume control of Western institutions and knowledge so as to run their own affairs. Through unauthorized, local Melanesian ways of internalizing whiteness, Dakoa's followers gained the strength and authority to resist the control and legitimacy of a new, bureaucratic Melanesian elite that was being moved progressively into the upper echelons of state and church. This Melanesian elite of councillors, kiaps, policemen, politicians, priests, and catechists was empowered by their own official alliance with Western governmental forms, and it was this Melanesian government of whiteness that cult followers contested with their own localized version of Melanesian whiteness that relocated it in the ground. The government of whiteness was embraced but so as to become an underground government known as kontrol bilong mipela (our control) that was used to sidestep direct governmental forms of control in the surface world.

It was through working with the ground that followers sought autonomy from surface white men and Western institutions, and it was this work with the ground that was defined as true self-government. When I queried Dakoa about patrol reports that claimed he was opposed to selfgovernment, he denied this, saying:

We spoke like this, "that we alone are Self, we are Self-government." ... It is not that we didn't like it, we liked Self[-government], Self we liked it. We didn't like youse masta coming and coming, for you come and you block [pasim] the thinking for us. So, for that reason, we wanted just ourselves. . . Y Yes, I wanted Self-government, for Selfgovernment is like this: it is just us, ourselves. It is not the white men who have come, it is just us alone, and this is its meaning which we follow. We wanted full government. We didn't want councils and all kiaps around, for they are just there to foul us. We just wanted full 
government where we'd be Self [government], we would be many villages and there would not be youse [whites] to foul us. We just wanted to sit down and work the thinking belonging to us, for our villages, for working coconuts, for working cocoa, for we know where the road is.

Self-government here is a question of finding one's own thoughts, of not having surface white men around to block, steer and sidetrack Melanesian self-development. Self-government here is of another local kind, and it stands in opposition to councils and the provincial and national governments, which were being pushed by the colonial administration as the true road to independence. For Dakoa, true independence will come from the ground, from D-supply, from other ways of working cash crops so as to steer into new forms of corporateness.

Yet the ground hides as much as it reveals, and the ground is above all a customary domain of secrecy and disclosure. Modernity in Melanesia has often been ambiguous; through being hidden or secreted away, modernity can then be redisclosed and regrounded in terms of other terrains of meaning. Here, history acquires a certain magic, with the new colonizing institutions and their accompanying processes of social change having their transformational effects remediated through the generative potential of the earth, through the generative potential of secrecy and disclosure. This often involves history becoming mythologized, that is, lived out through processes where Melanesian myths with their localities, familiar heroes, and biographical forms of narrative time become merged with Western spaces, colonial personnel, historical events, and civilizing processes. The consequences of this ambiguity are that the new forms of distance offered by Europeans - in the form of new bodies and identities, overseas Western countries, a future modern life, and a new afterlife (heaven and hell)-are merged with the distances or absences of a customary past (a lost god or ancestor, departed dead relatives, and invisible masalai). The customary mythic schemes for figuring a lost absence or for capturing an unseen presence are reemployed to figure and capture those new distances, absences, or gaps in meaning brought by whites.

We should not be surprised to discover globalization merging with local cosmologies, for to some extent mythic cosmologies have often been global in that they can articulate totalizing ambitions. In Papua New Guinea indigenous communities often perceive the all-embracing totalizing schemes of their cosmogonic myths as being remirrored in the all-embracing totalizing processes of globalization. The comprehensive, transformative aspects of mythic thought are perceived to be reevoked and reworked in the comprehensive transformative undertakings of modernity-of colonialism, Christianity, and capitalism. Here it is 
partly a question of modernity being experienced and lived as mythological, as a reenactment of original cosmogonic forces, with the forces of historical change becoming localized. However, it is also a question of local myths becoming historicised and globalized. The redemptive moral projects of government, church, and cash crops are here celebrated and embraced, becoming self-colonization processes whose true forms are reechoed through the ground, through an alternative government of whiteness mediated by the dead and masalai. The hegemonic conditions for making the modern world livable require new kinds of lies, new kinds of secrets, and new kinds of collusions with whiteness and modernity.

\section{Notes}

I The theoretical aspects of this article combine phenomenological and anthropological analyses of death and belonging (Feld 1982, 1996; Jackson 1989, 1995; Mimica 198I, 1988; Munn 197I; Weiner 1984, I99I) with a MarxistFoucauldian concern with pastoral power, race relations, hegemony, and tactics of resistance (Foucault 1977, 1982, I984; Hage 1998; Knauft 2002; Scott 1990; Taussig 1980, 1987).

2 By the late 1980 s most expatriate-managed plantations in New Britain had become insolvent.

3 Dakoa's followers often merge the Pisin word for overseas countries, kantri, with the Pisin word kandere, which is used to refer to maternal relatives and to familiar strangers. In a patrilineal society like Bali, whites as distant relatives are analogous to maternal relatives; they are analogous to the strangers one meets and befriends on plantations.

4 Dakoa also preaches that "money is love" because money cares for you; it loves you by buying you clothes, soap, and Western utensils. The cleaning and reordering of the self through commodities make the dead less afraid of the living so that the dead can draw close and again love their descendants.

5 Dakoa's customary clan Goloki is read as an acronym for the English words God and king.

6 Dakoa used to possess an English dictionary and he would study it so as to bring together various ambiguities. In the nine cult villages on Bali Island, cult church services often involve a blackboard where appointed cult leaders elaborate on the meaningful connections that key words and symbols set up across the racial divide.

7 Dakoa frequently blames the failures of cult promises and the departure of promising white men on the opposition of council supporters and on the time not being right.

8 Another white man regarded as sympathetic to the cult was an assistant manager at Bali Plantation. Known as Masta Bob, his friendship toward followers angered the local kiap. Cult folklore claims that he privately showed some followers a small, metallic object or pawa (power) that whites used secretly to create something out of nothing. He reportedly explained to Dakoa how the punishments they received were meant to stop them working hard so as to acquire 
this magical object. It was not, as followers thought, because their cult took laborers away from the plantation, followers away from the church and money away from government. Dakoa explained, "He said to me, "Now, why do you think the masta of the plantation is angry with you?' I said, 'He is angry with me because it would not be good if I worked all kanakas to come to my work and he didn't have any people for his work.' Then later he asked about the priest: 'Now why isn't the Father good toward you?' I said, 'Father is no good toward me because I have a church already and it would not be good if I took all kanakas for my church and he didn't have any.' [Masta Bob talking:] 'Now, what about the government? The government is cross with you for what reason?' I said, 'The government is cross because it says we are stealing money, that the money does not belong to us, it belongs to them.' Now, this man then said, 'No, that's not it. Its meaning is not like that. They are afraid of this here [shows him the small metal object or pawa]. It would not be good if you worked the work like you are and you acquired this here. For you would then break us and we wouldn't have something, this power.' He took it, brought it out and showed it to me and then he quickly hid it away in his pocket."

9 I believe Perukuma Company was unfairly punished through the taxation system. Given that it did not have labor costs, it generated a higher profit and thus a higher tax than otherwise would have been the case.

Io I do not believe these to have been real checks but pieces of paper with dollar figures.

II The American spirits who possessed followers complained how half of the money, which should have been forwarded on to the underground, never made it there but stayed with surface white men. Dakoa said, "Now, in the beginning we worked taxes to go to the office that we knew; and because all the whites had been friendly to us they received half the money and the other half of the money came to us. It continued like this up until the time they [underground dead] came and possessed [sitim] us and we then no longer gathered and sent money to them any more. This stopped. They [underground kandere] all spoke, 'They [above ground kandere] do work with us but they are also receiving half our money." "

\section{References}

Aquart, Helen E.

200I The Pomio Kivung Association, East New Britain. PhD diss., University of Newcastle, Australia.

Blythe, Jennifer M.

I992 Climbing a Mountain without a Ladder: Chronologies and Stories. Time and Society I: 45-50.

I995 Vanishing and Returning Heroes: Ambiguity and Persistent Hope in an Unea Island Legend. Anthropologica 37: 207-28.

Burridge, Kenelm

I960 Mambu. London: Methuen.

Counts, Dorothy Ayers

I968 Political Transition in Kandoka Village, West New Britain. PhD diss., Southern Illinois University, Carbondale. 
I97I Cargo or Council: Two Approaches to Development in Northwest New Britain. Oceania 4I: 288-97.

I994 Snakes, Adulterers, and the Loss of Paradise in Kaliai. Pacific Studies

Eliade, Mircea I7: 109-5I.

I954 The Myth of the Eternal Return. New York: Pantheon.

I959 The Sacred and the Profane. New York: Harcourt Brace Jovanovich.

I963 Myth and Reality. New York: Harper and Row.

Feld, Steven

I982 Sound and Sentiment. Philadelphia: University of Pennsylvania Press.

I996 Waterfalls of Song: An Accoustemology of Place Resounding in Bosavi, Papua New Guinea. In Senses of Place. Steven Feld and Keith H. Basso,

Foucault, Michel eds. Pp. 9I-I35. Santa Fe, NM: School of American Research Press.

I977 Discipline and Punish: The Birth of the Prison. New York: Vintage.

I982 The Subject and Power. Critical Inquiry 8: 777-95.

I984 On the Genealogy of Ethics: An Overview of Work in Progress. In The Foucault Reader. Paul Rabinow, ed. Pp. 340-72. New York: Pan-

Hage, Ghassan theon Books.

I998 White Nation: Fantasies of White Supremacy in a Multicultural Society. Sydney: Pluto.

Hegel, Georg. W. F.

I975 Aesthetics: Lectures on Fine Art. Oxford: Clarendon.

Heidegger, Martin

I977 Basic Writings. New York: Harper and Row.

Hermann, Elfriede

I992 The Yali Movement in Retrospect: Rewriting History, Redefining

Jackson, Michael "Cargo Cult." Oceania 63: 55-7I.

I989 Paths toward a Clearing. Bloomington: Indiana University Press.

I995 At Home in the World. Durham, NC: Duke University Press.

Kapferer, Bruce

I988 Legends of People, Myths of the State. Washington, DC: Smithsonian Institution Press.

I997 The Feast of the Sorcerer: Practices of Consciousness and Power. Chicago: University of Chicago Press.

Kaplan, Martha

I995 Neither Cargo nor Cult: Ritual Politics and the Colonial Imagination in Fiji. Durham, NC: Duke University Press.

Knauft, Bruce, ed.

2002 Critically Modern: Alternatives, Alterities, Anthropologies. Bloomington: Indiana University Press.

Lattas, Andrew

I998 Cultures of Secrecy: Reinventing Race in Bush Kaliai Cargo Cults. Madison: University of Wisconsin Press.

I999 Neither Cargo nor Cult. Anthropological Forum 9: I07-I2.

2000 Telephones, Cameras, and Technology in West New Britain Cargo Cults. Oceania 70: $325-44$. 
200I The Underground Life of Capitalism: Space, Persons, and Money in Bali (West New Britain). In Emplaced Myth. Alan Rumsey and James

Lawrence, Peter Weiner, eds. Pp. I6I-88. Honolulu: University of Hawai'i Press.

I964 Road Belong Cargo. Melbourne: Melbourne University Press.

Lindstrom, Lamont

I993 Cargo Cult-Strange Stories of Desire from Melanesia and Beyond. Honolulu: University of Hawai'i Press.

LiPuma, Edward

2000 Encompassing Others: The Magic of Modernity in Melanesia. Ann Arbor: University of Michigan Press.

McCarthy, Jack K.

I964 Patrol into Yesterday. Melbourne: Cheshire.

McPherson, Naomi

I994 The Legacy of Moro the Snake-Man of Bariai. Pacific Studies I7: I53-8I.

McSwain, Ramola

I994 Kulbub and Manub: Past and Future Creator Deities of Karakar Island.

Mimica, Jadran Pacific Studies I7: II-28.

I98I Omalyce: An Ethnography of the Ikwaye View of the Cosmos. PhD diss., Australian National University, Canberra.

I988 Intimations of Infinity. Oxford: Berg.

Munn, Nancy D.

I97I The Transformation of Subjects into Objects in Walbiri and Pitjantjatjara Myth. In Australian Aboriginal Anthropology. Ronald Berndt, ed. Pp. I4I-63. Nedlands: University of Western Australia Press.

Oppermann, Thiago C.

2003 The Conquest of the Irrational: Scenes from an Attempt at Nation

Pech, Rufus Building. MPh diss., University of Sydney.

I99I Manub and Kilibob: Melanesian Models for Brotherhood Shaped by Myth, Dream and Drama. Point Series I6. Papua New Guinea: Melanesian Institute.

Pomponio, Alice

I994 Namor's Odyssey: Mythical Metaphors and History in Siassi. Pacific Studies I7: 53-9I.

Povinelli, Elizabeth

I993 Labor's Lot: The Power, History, and Culture of Aboriginal Action. Chicago: University of Chicago Press.

Sahlins, Marshall

I98I Historical Metaphors and Mythical Realities. Ann Arbor: University of Michigan Press.

Scott, James C.

I990 Domination and the Arts of Resistance. New Haven, CT: Yale University Press.

Taussig, Michael

I980 The Devil and Commodity Fetishism in South America. Chapel Hill: University of North Carolina Press.

I987 Shamanism, Colonialism, and the Wild Man. Chicago: University of Chicago Press. 
1999 Defacement: Public Secrecy and the Labor of the Negative. Stanford, CA: Thurston, William Stanford University Press.

I994 Legends of Titikolo: An Anim Genesis. Pacific Studies I7: I09-52. Valentine, Charles A.

I955 Cargo Beliefs and Cargo Cults among the West Nakanai. Miscellaneous typescript reports, Pacific Manuscripts Bureau. National Library, Canberra. Microfilm.

Weiner, James

I984 Sunsets and Flowers: The Sexual Dimension of Foi Spatial Organisation. Journal of Anthropological Research 40: 577-88.

I99I The Empty Place. Bloomington: Indiana University Press.

Worsley, Peter

I970 [1957] The Trumpet Shall Sound. London: Paladin.

Young, Michael

I983 Magicians of Manumanua. Berkeley: University of California Press. 